slides aseismically, loading the locked patches towards failure. Moderate earthquakes, such as the 1966 event, occur during failure of the left patch shown. Otherwise, the stress increase on and near locked patches generates background seismicity and deformation of the ground surface.

In the revised model, seismicity and geodetic-rate decreases are caused by slip on a sub-horizontal fault ( $\mathrm{H}$ in figure) beneath the locked patches. The same deep slip on the San Andreas fault that loads the locked patches also loads a horizontal plane at $\mathrm{H}$, and if the plane's yield stress is a little less than that of the overhead patch, then the horizontal fault will slip first. Slip on the horizontal fault will be late in the seismic cycle and will decrease the loading rate on the vertical fault and adjacent crust. The postulated fault may be part of the sub-horizontal detachment fault associated with the magnitude 6.7 Coalinga earthquake in 1983 , $40 \mathrm{~km}$ northeast of Parkfield. In short, seismicity and crustal motion slow down late in the earthquake cycle because the detachment fault, acting as a buffer, comes to life.

The reason for seeking precursory anomalies is, of course, to make short- or intermediate-term earthquake predictions. The advantage of such predictions is that they may be more precise than longterm ones. Long-term predictions (more than a few years), such as those derived from earthquake-recurrence intervals, usually have uncertainties of many years. This is true even when long-term predictions are refined using conditional probabilities to allow for the time elapsed with no earthquakes ${ }^{3}$. As Savage suts $^{8}$ it, the probabilities are uninformative because the acceptable range of probability values is so great.

The empirical approach of Wyss et al. ${ }^{2.7}$ is one way to make an intermediate-term prediction from observations. But their work also places within reach a mechanical model connecting background seismicity, crustal deformation and a forthcoming mainshock. A detailed and accurate model might therefore be adapted to forecast earthquakes just as atmospheric models are used to forecast the weather.

William D. Stuart is at the US Geological Survey, Pasadena, California 91106, USA.

\footnotetext{
1. Bakun, W.H. \& Lindh, A.G. Science 229, 619-624

2. Wyss, M., Bodin, P. \& Habermann, R.E. Nature $345,426-$ $428(1990)$

3. US Geol. Surv. Open-File Rep. 88-398, (USGS, 1988).

4. Aviles, C.A. \& Valdes, C.M. Eos 70, 1228 (1989).

5. Reasenberg, P.A. \& Matthews, M.V. Pure appl. Geophys. 126. 373-406 (1988).

6. Matthews, M.V. \& Reasenberg, P.A. Pure appl. Geophys.

126, 357-372 (1988).
7. Wyss, M. Slater, L. \& Burford, R.O. Nature 345, 428-431 (1990).

8. Savage, J.C. Seismol. Res. Lett. 61, 43 (1990).
}

\section{Consensus for conservation}

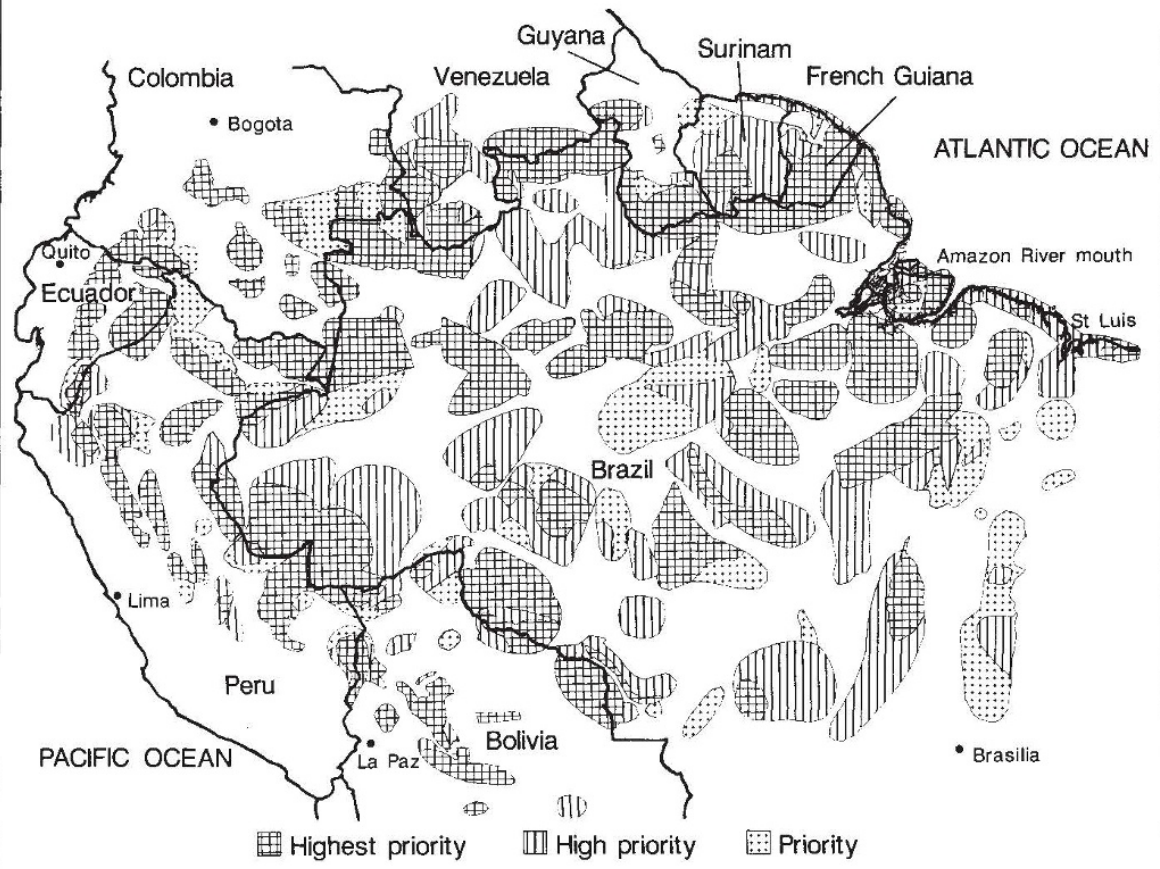

THE map reproduced here, the fruit of a recent interdisciplinary meeting*, identifies the areas of biological priority for conservation in Amazonia, graded into three levels. The total area shaded covers about 60 per cent of the Amazon basin and the areas with square hatching are of greatest biological importance. The map represents the consensus of some 100 biologists, physical scientists and conservation planners - it will be an essential tool in planning the location of biological reserves, national parks, extractivist reserves and other conservation areas in Amazonia.

Scientists at the meeting began by working in small specialist groups: plant systematics, plant ecology, mammals, ornithology, herpetology, icthyology, entomology, geomorphology and climate, and units of conservation. The seven biological groups each produced thematic maps to justify their selection of priority areas. This was followed by separate meetings of botanists and zoologists to pool their data and consolidate their chosen areas on maps for botany and for zoology; as it turned out the areas selected by the different groups broadly corresponded. At the same time, the geomorphologists and climatologists produced a map identifying the most fragile soils and the ecosystems requiring the greatest protection. The conservation unit's group discussed policy and other factors bearing on the preservation, conservation and management of priority areas.

The last step was the fusion of the 104

*Workshop 90, Manaus, Brazil, 10-20 January 1990 areas of biological importance for botany with the areas selected by zoologists. The final map shows 94 priority areas, evaluated on a five-point scale (eventually reduced to three). Areas with the maximum overlap between disciplines were given the highest priority.

Much on-site work remains to be done by conservation organizations of the nine countries concerned, to select the precise areas suitable for different categories of reserves, managed forests and regions for the indigenous population. The shaded parts of the map include some deforested and inhabited areas and site visits are necessary to locate suitable reserves. But the biologists have provided their data, and now it is the turn of conservation planners to choose appropriate reserves, politicians to make them a reality and international assistance organizations to help finance them.

What of the white areas? Are these the regions in which deforestation should be allowed to proceed? They are indeed probably of less importance in terms of species diversity, but the state of inventory of the Amazon region is still so poor that it would be unwise to advocate development projects in these spaces that, in many cases, represent some of the least explored parts of Amazonia. These are areas that need to be chosen for further inventory, rather than for deforestation. Ghillean T. Prance

Ghillean T. Prance is at the Royal Botanic Gardens, Kew, Richmond, Surrey TW9 3AB, UK. 